\title{
CHANGING PATTERS OF WATER CONSUMPTION IN THE SUBURBAN BARCELONA: LIFESTILES AND WELFARE AS EXPLANATORY FACTORS
}

\author{
Elena Domene $e^{1}$ \\ Institut d'Estudis Regionals i Metropolitans de Barcelona (IERMB)
}

\begin{abstract}
Atlantic gardens and swimming pools constitute one of the most relevant features of a new phase in the history of the urbanization process in the Metropolitan Region of Barcelona, coinciding with the real state "madness", by which the traditionally compact urban form typical of Mediterranean cultures lose ground to more disperse patterns of settlement characteristic of Anglo-Saxon countries. The change in the urban form also bears a noticeable relationship with changing lifestyles more and more akin to the suburban landscapes of many areas of Atlantic Europe and above all North America. Low density housing with gardens and swimming pools are associated with a better quality of life and considered as positional goods, giving the owners the status and prestige that is absent from other urban forms. In this paper I will therefore illustrate how new "suburbia lifestyles" linked to water use are gaining terrain in a geographical, social and cultural context that traditionally has been quite conservative in the use of this resource. I will show also how new, water-related lifestyles are endowed also with a strong income component. Thus high income households prefer and can afford more water-consuming Atlantic gardens with swimming pools whereas lower income households have to resort to more climate-adapted species in what constitutes a growing socio-spatial differentiation.
\end{abstract}

Keywords: urbanization, water consumption, gardens, suburban lifestyles, Barcelona, uneven development.

\section{RESUMEN}

Cambio en los patrones del consumo de agua en la Barcelona suburbana: estilos de vida y renta como factores explicativos.

Los jardines atlánticos y las piscinas constituyen una de las características más relevantes de esta nueva fase en la historia del proceso de urbanización en la Región Metropolitana de Barcelona, coincidiendo con la "locura" constructora por la cual la tipología de urbanización tradicionalmente compacta típica de las culturas mediterráneas pierde terreno frente a los tipos de urbanización más dispersos, típicamente característicos de los países anglosajones. El cambio en el modelo urbano también conlleva una constatable relación con los cambios en los estilos de vida cada vez más típicos de los paisajes suburbanos de muchas áreas de la Europa atlántica y sobre todo de Norte América. Casas en urbanizaciones de baja densidad, con jardines y piscinas están directamente asociadas con una mejor calidad de vida y considerados como bienes posicionales, dando a sus propietarios un estatus y prestigio que no se encuentra en otras formas urbanas. En este documento, por tanto, ilustraré como estos nuevos "estilos de vida suburbanos" que están relacionados con un intenso consumo de agua están ganando terreno en un contexto geográfico, social y cultural que tradicionalmente ha sido bastante conservador en el uso de este recurso. También mostraré como estos nuevos estilos de vida están asimismo interrelacionados con un fuerte componente de nivel de renta. De tal forma, hogares de alta renta prefieren y se pueden permitir jardines atlánticos

Contacto: elena.domene@uab.cat

1 Edifici MRA, Autonomous University of Barcelona. E-08193 Bellaterra, Barcelona, Spain. 
más consumidores de agua, y con piscina, mientras que los hogares de baja renta tienen que recurrir a especies más adaptadas climáticamente, en lo que constituye una creciente diferenciación socioespacial.

Palabras clave: consumo de agua, urbanización, jardines, estilos de vida suburbana, Barcelona, distribución desigual.

\section{INTRODUCTION}

Since the 1950s, the development of metropolitan regions in most regions of North America and Northwestern Europe has been dominated by population deconcentration, favoured by increases in wealth, expanding car ownership, the improvements in road and rail networks and the decentralization of industries and jobs away from the city cores. Under these circumstances of social and economic changes, concerns over quality of life increased also in what has been called the paradox of the affluence, meaning that the interest in quality of life issues increase proportionately to technological progress and income growth (Hirsch, 1976; Pacione, 2003). In a search for a better quality of life large parts of the population abandoned the central city looking for what they considered a better place to live: a detached or semidetached house with a private garden in a rural o suburban area. Increasing awareness of the importance of other non-economic factors, such as social and environmental, led to an urban way of life based on a low density urbanization pattern always relatively far from the core of the city.

Low density urban growth, characteristic from North America and Western Europe, began its process of introduction into Southern Europe since the beginning of the 1980s. In some of these countries, such as Spain, low density settlements placed mainly in the periphery of the main metropolitan areas arose due to two different processes, not overlapped in time. The first process was the increase in the number of secondary homes for weekend of vacation purposes near the highly dense cores of metropolitan areas during the 1960s and the 1970s. The second process was the proliferation of permanent single housing, especially condominiums, during the 1980s and 1990s. The conversion of second housing into permanent housing, together with the so called second wave of urbanization in the suburbs, evolved into the depopulation of the metropolitan city cores and the increase of the population in the peripheral areas of these city cores. As a result, in cities such as Barcelona, Madrid, Seville, Valencia and others, a new suburban landscape began to grow. New housing types brought along the increase of new outdoor activities typical of suburban areas, such as the increasing presence of gardens with grass and other species of plants not native of Mediterranean regions, swimming pools, ornamental fountains, and other water-related amenities. As a result of this, domestic water consumption in the Mediterranean areas, and its quite frequent experience in water shortages, has changed. Under the assumption of a decline of the water availability in Southern and South-Eastern Europe (by $10 \%$ or more in some river basins by 2030) (European Environmental Agency, 2007; M. Trnka et al., 2011) more pressure in the water resources is to be expected in the future.

The association between urban sprawl and higher resources and land consumption is already well known (Newman, 1992; Breheny, 1992; European Environment Agency, 2006). In what concerns water consumption, there is abundant literature attempting to explain influencing factors on this consumption, especially in the economics (Martínez-Espiñeira and Nauges 2004). Much attention has been paid to the economic, demographic, urban and social factors influencing urban water consumption. Cultural aspects, however, have been less analysed. I argue that suburban landscapes, as the spatial expression of cultural, social and physical processes, are integral to how consumption processes are constituted and articulated and that water-related consumption in gardens and swimming pools is endowed with important connotations of power and social expression, leading to important distributional inequities.

The main aim of this article is to explore the association between suburban landscapes and water consumption from a geographical perspective, with an attempt to better understand the links between socio-cultural and physical processes taking place during the process of suburbanization. In doing so I want to analyse the symbolic representations of this landscapes, the role of market in shaping a particular ideal of the home and the ways in which these processes may lead to uneven social and territorial development. All these questions are explored through the examination of the urbanization process of the Metropolitan Region of Barcelona (MRB) during the first decade of the $21^{\text {st }}$ century, coinciding with a period of economic and real estate booms in Spain and a significant residential mobility. 
I will attempt to illustrate how new patterns of consumption manifested by the expansion of turf grass gardens and swimming pools in the MRB convey images of the suburban dream adapted to a Southern European context but also how this process also encompasses deep social and environmental inequities, manifested for instance in larger appropriations of a critical resource such as water by the affluent classes of the suburbs. These, irrigate their highly consuming gardens and fill their swimming pools thus reaffirming their economic power and social status over the less favoured classes of the inner cores.

The first section briefly presents the association between consumer culture and suburban landscapes, and explores the symbolic representation of these spaces and the role of gardens in creating personal identity. The second section uses secondary empirical data to examine the process of urbanization in the Barcelona Metropolitan area, the changing patterns of water consumption in the MRB, and the role of gardens and swimming pools in shaping different geographies of water consumption. I also highlight the factors influencing the water consumption in this context and the spatial and social inequities of this urban model. Finally I attempt to evaluate the role of market and advertising in creating a particular ideal of the home and suburban life, based in different promotions in real estate developments in the period of the construction boom. It is important to remark that the results and discussion of this work must be understood in the context of the economic and real estate boom previous to the current Spanish crisis beginning in 2008, and also previous to the worst drought in decades in Catalonia occurring in 2008.

\section{SUBURBAN LIFESTYLES AND CONSUMER CULTURE}

Consumption is becoming one of the key concerns in social sciences and more specifically in urban studies. Consumer perceptions, actions and experiences have an important role to play in urban social life, and consumption has emerged as a fundamental focus for social expression (Miles and Paddison, 1998). On the other hand, consumption also helps us understand how the contextual use of natural resources is perceived and experienced (Hobson, 2003). Cities are no longer seen as spaces of production but spaces of consumption (Zukin, 1991). In addition, there is a growing acknowledgement about the need to establish links in the consumption-related aspects of globalization in order to understand both the effects of changing cultural styles and practices related to material consumption, and the environmental consequences of this consumption (Leichenko and William, 2005).

Consumption presents a high component of social expression necessary to understand suburban lifestyles. Already at the beginning of the 20th century, Georg Simmel (1903) understood consumption as an essential focus for social expression in the modern world. He described consumption as fundamental with respect to how individuals express themselves in the urban market places.

Thorstein Veblen (1899, ed.1965) saw consumer goods as markers of social prestige and status. He analysed the "nouveaux riches" of New York 100 years ago and argued that it was the desire of the middle and upper-middle classes, described by him as the "new leisure class", to adopt the consumer patters of the upper-class what was inducing increases in consumption. Hence, consumption attained a relevant social status component. Veblen elaborated a system of ranks and grades depending of consumption which expressed the position of each segment of the population in the social hierarchy of the leisure classes. However, Veblen's concept of emulation has been criticized as he considered consumers as unthinking individuals. Despite this and other criticisms, Veblen's work has been important in highlighting, on the one hand, the relationships between economy and culture in shaping consumption as a significant social practice and, on the other, the recognition of the symbolic component of consumption (Mansvelt, 2005).

In Social Limits to Growth, Fred Hirsch also argued that "... as the level of average consumption rises, an increasing portion of consumption takes on a social as well as an individual aspect. That is to say, the satisfaction that individuals derive from goods and services depends in increasing measure not only on their own consumption but on consumption by others as well" (Hirsch, 1976, Ed. 1995, p.2). This statement led to his well-known concept of "positional goods". Positional goods are scarce in some absolute or socially imposed sense or else subject to congestion or crowding through more extensive use. For this reason they become more attractive with growing prosperity. Examples of positional goods are high levels of education, houses in specific locations, etc. According to this argument, consumption has 
an important component of social interaction. It does not depend on the absolute (or physical) scarcity of goods and services but on a relative (or social) scarcity. When the basic needs are covered, consumers tend to direct their decisions towards goods and services that bestow prestige, distinction and status.

From a more post-modern approach, some authors realize that "the academic critique of consumerist conformity has turned into a celebration of choice, identity in and through goods" (Cross, 2000). Through consumption, consumers can feel that they belong to something. In the post-modern context, people appreciate their individuality and want to choose goods and consumption which bring them things such as uniqueness and distinctiveness. In post-modern times, commodities are assumed to have a more significant role in mediating social life than previously. In this sense, consumption becomes driven by fantasies feeding aspirations which cannot be fully satisfied, resulting in a constant search for goods which make possible the self-fashioning of a lifestyle and an identity space (Friedman, 1994). Moreover, consumption is promoted in popular culture and media offering self-realization, happiness and fulfilment (Douglas, 2000).

The rise of suburbia and the rise of sub-urbanization is a clear testimony to the role of citizens as consumers (Hirsch, 1976). Different symbolic and material practises lead to different spaces of consumption remaking landscapes and transforming local cultures (Mansvelt, 2005). Surburban settings have been considered the places in which natural resources and land consumption attains its maximum expression. Hirsch already used the case of suburbanization as an example of positional goods to explain the effect of the allocation of resources according to social patterns.

Through consumption, suburban areas foster lifestyles that embody symbolic representations of individual autonomy and civic pride within communities. In North America suburban lifestyle has been considered the "right mode of life" (Carney, 2007). Although suburban types have grown and are far more complex that the stereotypes of mono-functionality and family-based environments, middle and high class North American suburban landscapes with lawns are still mainly produced in association with social matter such as family, community and connections to the environment (Robbins and Sharp, 2003). The garden takes a predominant role in the suburban model, especially in North America. The lawn as an American way of life has been present in the American literature of the last decade (Bormann et al., 1993; Scott, 1994; Tessyot, 1999; Steinberg, 2006). The literature on American lawn makes evident Americans love their lawns, viewing them as signs of opulence, leisure, and achievement (Robbins, 2007). In the North European context, meanings such as being outside, privacy, freedom and gardening are also presence in private domestic gardens (Coolen and Meesters, 2012) and there is substantial evidence that people living in suburbs are satisfied with their place of residence (Lupi, 2003).

\section{THE PROCESS OF SUB-URBANIZATION IN THE METROPOLITAN REGION OF BARCELONA (MRB)}

The MRB is experiencing the process of suburbanization (Figure 2) with some delay with respect to Northwestern Europe and North America but mirroring patterns of urban development based on low density urbanization, with gardens and swimming pools playing an important role (Catalan et al., 2008). The MRB is structured in a very dense core with 1.5 million people, a first periphery also densely populated, a second periphery, based on low density patterns of settlement, and finally, a total of six subcenters or cities with more than 50.000 people in 1996 (see Figure 1) (Lleonart and Garola, 1998; Nel.lo, 1995). In total, the population of the MRB was 4.2 million at the end of the 1990s.

In the 1950s and 1960s, large numbers of immigrants from other areas of Spain arrived in Catalonia searching for jobs. These decades observed the highest rates of population growth recorded in the history of the MRB. The successive immigration waves also increased birth rates to the point that generations born between 1965 and 1975 constitute the largest group ages of the region. Barcelona and especially neighbouring cities absorbed much of this growth. The dominant urban form was one of high density in low quality housing blocks built in the periphery of Barcelona to accommodate immigrants and their families in flats often smaller than 60 square metres. In all, between 1960 and 1975, population in the MRB grew from 2.5 to 4 million people. 
Figure 1. Metropolitan Region of Barcelona

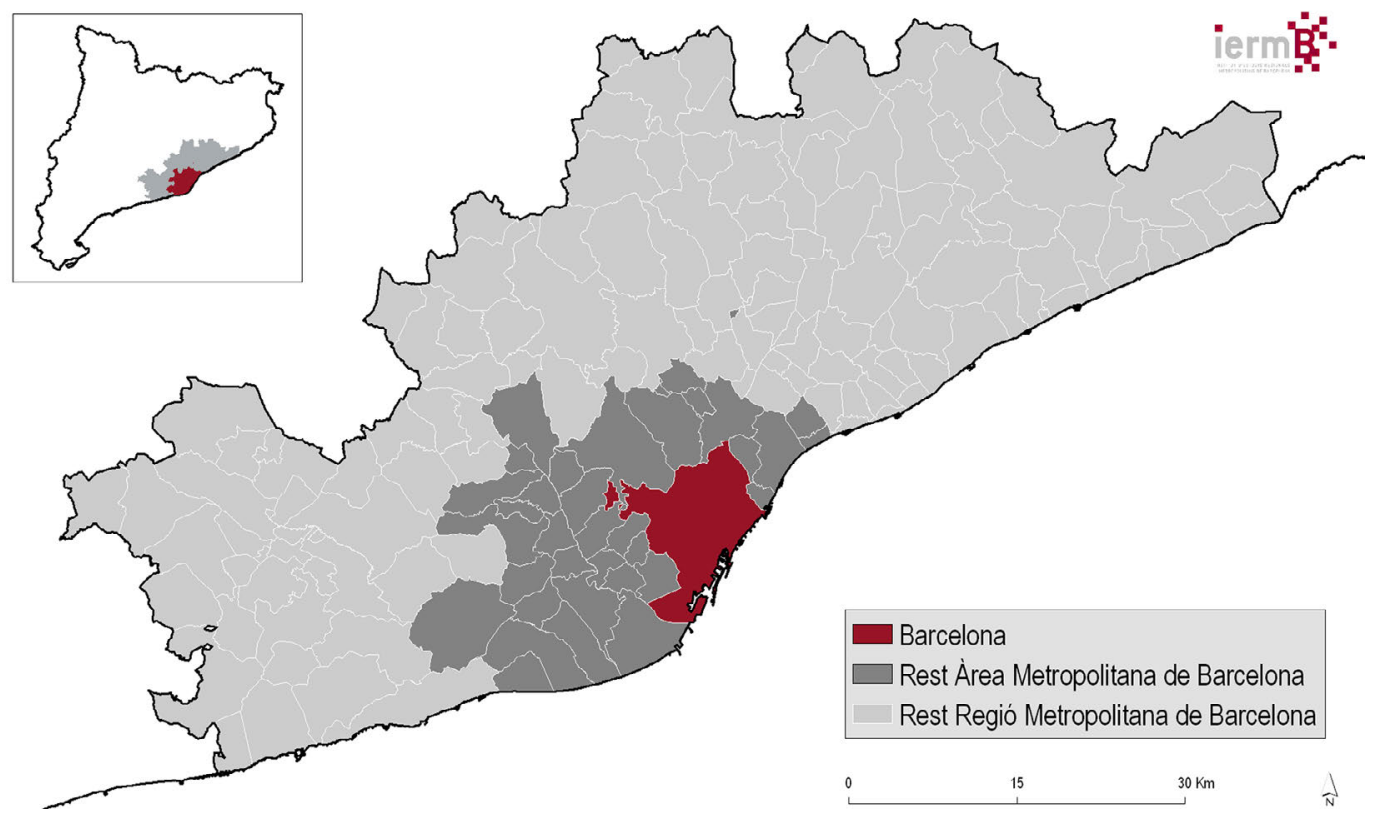

Figure 2. Population in the Metropolitan Region of Barcelona (1975-2011)

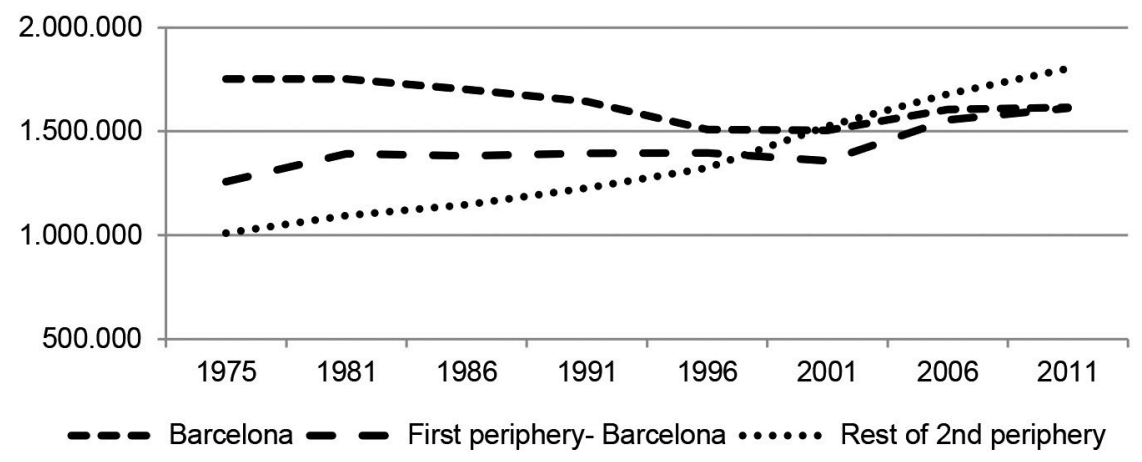

Source: Calculated from data of the Institut d'Estadística de Catalunya

Rueda analyzes the environmental cost of the low-density urban pattern, especially in relation to the loss of land to urbanization and the fragmentation or degradation of the remaining areas (Rueda, 1995). According to Nel.lo, urbanization based on low-density patterns is functionally inefficient, and socially and environmentally unsustainable. One reason for this is the extremely high increase in the need for private transportation and transportation infrastructure (Font et al., 1999, Nel-lo, 1995). Muñoz, defining the "escape" to the suburbs as "urbanalization", argues that functionally segregated urban patterns foster a decrease of social complexity, simplicity of the urban design and, consequently, a loss of community attachment and weaker social networks. Moreover, low density residential areas increase the public cost for infrastructures, public transport and other public services. These costs have to be paid also by people living in central cities who could not enjoy the benefits of the suburban life (Muñoz, 2001).

As long as the current urban patterns continue, the traditional Mediterranean city could lose its compactness, diversity, and functional and social complexity to what in the Mediterranean context has been defined as "diffuse" city (Indovina, 1990). Actually, the traditional Mediterranean city already extends in a similar ways to North-American suburbs, with the well-known features of decreases of the population density, generalization of single-family housing and increases of land consumption, a more intense filtration of the property market, and lack of efficient urban planning (Camagni and Gibelli, 2002). Still, cur- 
rent Mediterranean cities are a mixture of the two models: compactness in the city centre and the so-called "dorm-cities" of the 1960s and 1970s, and dispersion in new residential areas of the 1980s and 1990s.

Dura-Guimera (2003) argues that future urban developments in the Mediterranean will not resemble much their North-American counterparts because of remarkable cultural differences in family structure and social preferences between the two areas. Using the case of the MRB he identified the migration to the suburbs as a symptom of failure for the low and middle income classes because their lifestyles are highly dependent on the family and urban sprawl increases the distance between family members. Furthermore he claimed that there is no special desire in the upper classes for living in the suburbs, since they enjoy the compact city and own a secondary residence for weekends and vacations. However, these assertions raise strong doubts. Southern European cities are not immune to global processes affecting European cities. LeGales (2002), for instance, argues that European cities are becoming more de-territorialized due to growing connections to global networks. In this sense, then, there appears to be a convergence between European cities of the North and the South independently of the urban form. Moreover, at the outer periphery of the MRB, more than three quarters of citizens think that their quality of life is better that those who live in the city, pointing to the problems of overcrowding, traffic congestion and environmental pollution (IERMB, 2006)

\section{NEW WATER CONSUMPTION GEOGRAPHIES}

\subsection{Changing patterns of water consumption in the Metropolitan Region of Barcelona}

The suburbanization process is especially relevant in what concern domestic water consumption in a context of relatively frequent water shortages experienced by the MRB during the last fifteen years. Households with substantial presence of swimming pools and gardens have higher water consumption than those without outdoor uses. Residential water consumption is moreover creating important distributional inequities in the region. Average residential water consumption is increasing in municipalities of the periphery where a proliferation of gardens and swimming pools exists. On the contrary, water consumption in municipalities following a dense urban form tends to stabilize or even decrease in recent years (Figure 3).

Figure 3. Domestic water consumption per capita (litres/person x day) (2005-2010)

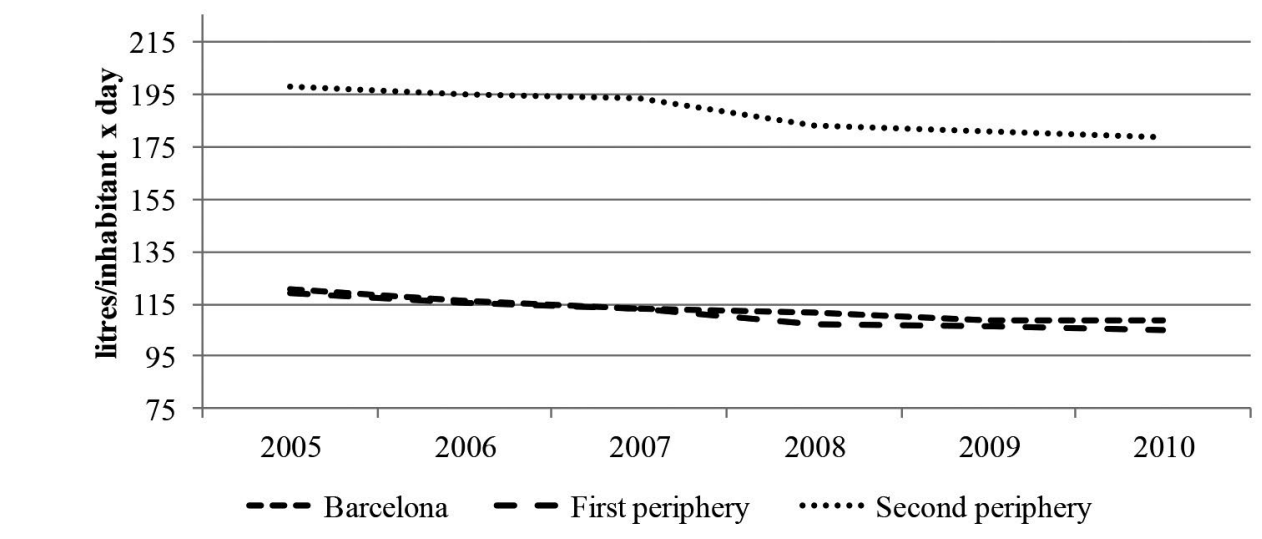

Source: Calculated from data of the Institut d'Estadística de Catalunya and Dades Ambientals Metropolitans AMB.

In the case of the MRB, people moving from the city core to peripheral areas adopt new consumption patterns unknown when living in the compact city. The socio-economic and demographical reasons for moving from the highly populated areas to the outer spaces of the region have been already pointed out. Economic growth and the boom of the construction sector in Spain contributed to the increase of consumption in the housing sector. In addition, the search for a certain lifestyles and the individual preferences may have also played an important role when choosing a certain type of housing, especially among the middle and upper classes. The resulting changes in everyday practice have profound implications 
for consumption patterns within the household sector, especially for energy and water (Figure 4). Figure 4 shows a strong correlation among electricity, water and waste generation in the domestic sector in the MRB, leading to the conclusion that low density models with gardens and swimming pools consume more water, but also more electricity and other materials.

Figure 4. Relationship between electricity consumption, water consumption and waste generation in the domestic sector in the Metropolitan Barcelona (2008)
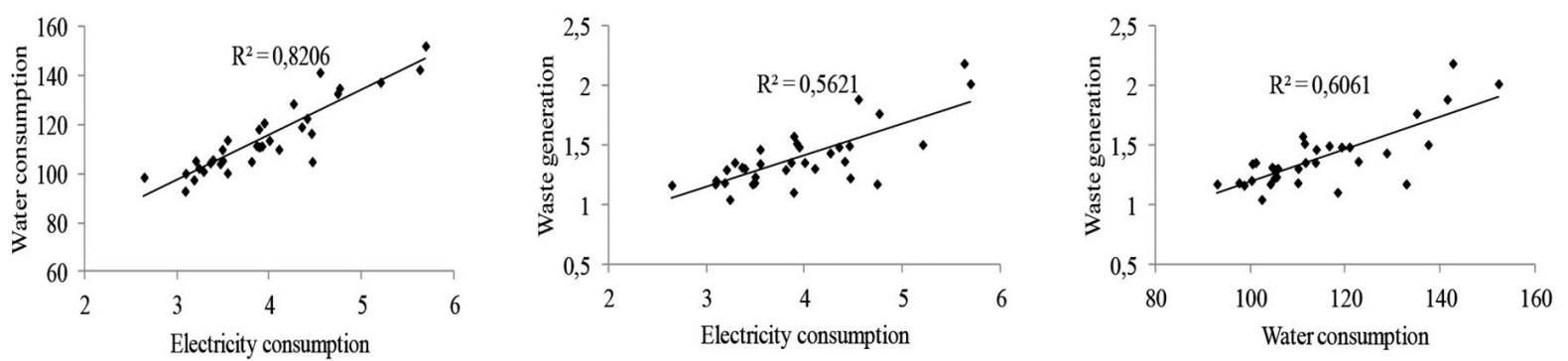

Source: Calculated from data of the Institut d'Estadística de Catalunya, Institut d'Energia de Catalunya and Dades Ambientals Metropolitans AMB. .

As mentioned before, residential water consumption is not equally distributed but remains higher in the second periphery. Moreover, in the last decades municipalities losing population present lower per capita water consumption in the domestic sector, whereas the municipalities where rates of population growth are higher have also higher per capita domestic water consumption. The former tends to be based on high density housing, while the latter are more based on low density - single-family or detachedhousing type (Figure 5).

Figure 5. Relationship between percent of population change (2001-2011) and domestic water consumption in the Metropolitan Barcelona(2011).

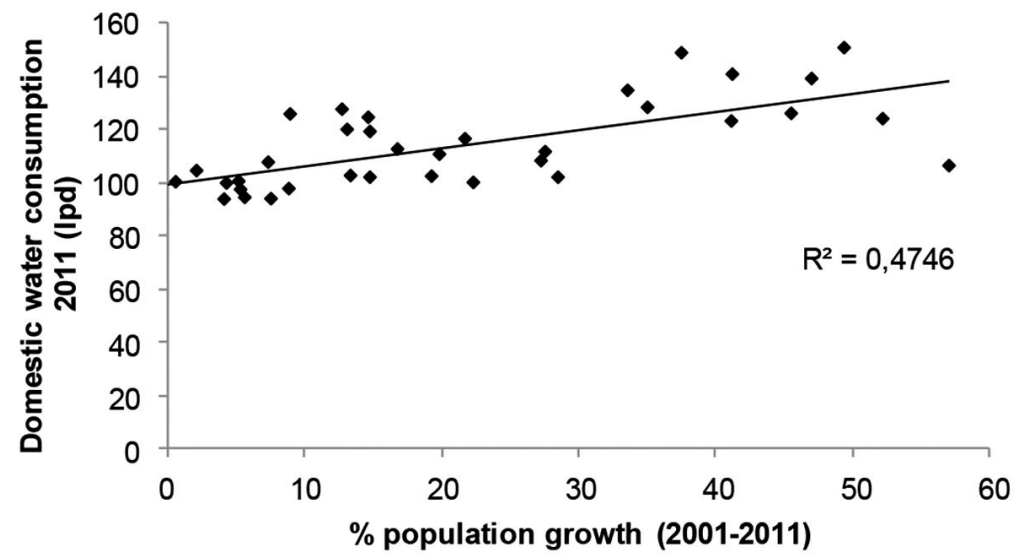

Source: Calculated from data of the Institut d'Estadística de Catalunya and Dades Ambientals Metropolitans AMB.

\subsection{Water consumption explanatory factors in the Metropolitan Region of Barcelona}

Overall, price is pointed to by most econometric studies as a critical variable influencing domestic water consumption (see Arbués, García-Valiñas, and Martínez-Espiñeira 2003; Martínez-Espiñeira and Nauges 2004). However, a more comprehensive view of domestic water demand would lead to the consideration of other factors that also might explain the differences among individuals, cities, or even countries (Dziegielewski 1999; Stephenson, 1999; Mazzanti and Montini 2006). Although the academic and professional literature on this subject still focuses mostly on Anglo-American case studies (see, e.g., Foster and Beattie 1981;Hanke and de Maré 1982; Opaluch 1982; Agthe and Billings 1997; Baumann, Boland, and Hanemann 1998; Duke, Ehemann, and Mackenzie 2002; Martínez-Espiñeira 2002; Arbués, 
García-Valiñas, and Martínez-Espiñeira 2003; Nauges and Thomas 2003; Hoffman, Worthington, and Higgs 2006), it has also begun to introduce sociodemographic and climatic factors as important influences in consumption. Income (determining the budgetary restriction of the consumer) (Domene, 2006; Domene et al. (2005)), household size (economies of scale in the consumption of water) (Loh and Coghlan, 2003), or aging of the population, together with rainfall and temperature (influencing the water needs of garden species) (Miaou, 1990; Syme, 2004), have been increasingly taken into account in these studies (Arbués, García-Valiñas and Martínez-Espiñeira, 2003), although not usually at the same time. However, and possibly because of the Anglo-American bias, few contributions deal with the relevance of the predominant urban model (high density or low density) and associated urban lifestyles in shaping consumption patterns and behaviours.

In particular, factors conditioning residential water consumption in the MRB can be summarized as follow (Domene and Saurí, 2006). First, housing and demographic factors may be significant explanatory variables of domestic water consumption. In particular, household size and housing type appear to be important factors behind consumption. Small families show higher per capita domestic water consumption than larger ones and single-family houses have higher water consumption mainly because of outdoor uses, especially gardens. Most of all, high water consumption is associated with single-family housing with an 'Atlantic garden', planted with turf grass. Secondly, water consumption is not constant across incomes and the relationship is positive in all housing types. Moreover, the positive effect of income is more relevant when outdoor uses are present.

Thirdly, consumer behaviour also plays an important role as an explanatory factor, although attitudinal variables seem to be less important than sociodemographic and economic variables. Fourthly, average water prices do not appear to be significant in the MRB, except during the winter season and for high-density households. This can be explained, partly, by the fact that consumers do not perceive the water associated with their necessities as too costly. In addition, the expenditure required for water uses represents on average about 1 per cent of the total household budget. However, this may have changed substantially with the current economic crisis and the sharp increases in water prices and taxes in the Barcelona area since 2010.

The main contributing factor in this higher per capita domestic water consumption is the presence of outdoor uses such as private gardens and swimming pools. In single-family households with a garden the amount of water consumed in summer adds to 50 percent of the annual amount (Domene and Saurí, 2003). Moreover, there is an increasing preference for "Atlantic" gardens with turf grass as the main component, especially in the most well-of neighbourhoods. As turf grass is not well-adapted to the Mediterranean climate, these garden types require high quantities of water to be maintained under good aesthetical conditions. The total amount of water used to irrigate the private gardens of the MRB has been estimated in $40 \mathrm{Hm}^{3} /$ year (the total amount of water for residential uses is about $375 \mathrm{Hm}^{3} /$ year) (Domene et al., 2005).

Swimming pools also appear as a relatively new and relevant suburban consumption that extends all over the region. In 2001, there were around 54,000 residential swimming pools in the MRB (Table 1) (Vidal and Domene, 2005). Together they would form an area of 1.64 square kilometres, with a total estimated annual consumption of a little over 3 cubic hectometres (cuHec) per year (Vidal et al., 2011).

Table 1. Distribution of swimming pools and their relative water consumption in the MRB, 2001.

\begin{tabular}{lccccc}
\hline & $\begin{array}{c}\text { Number } \\
\text { of pools }\end{array}$ & $\begin{array}{c}\text { Pools/1000 } \\
\text { people }\end{array}$ & $\begin{array}{c}\text { Single houses } \\
\text { with pools \%* }\end{array}$ & $\begin{array}{c}\text { Water } \\
\text { consumption } \\
\mathbf{m}^{3} / \text { year }\end{array}$ & $\begin{array}{c}\text { Water } \\
\text { consumption } \\
\text { lpd }\end{array}$ \\
\hline Barcelona & 1,266 & 0.84 & 5.74 & 103,512 & 0.16 \\
lrst metropolitan ring & 12,238 & 9.15 & 18.35 & 829,158 & 1.43 \\
$2^{\text {nd }}$ metropolitan ring & 36,390 & 41.08 & 20.82 & $2,465,701$ & 6.40 \\
Subcentres & 4,318 & 6.51 & 7.40 & 251,679 & 0.87 \\
\hline
\end{tabular}

*Per cent over all residential units. Lpd: litres/person x day 
As said, in the Mediterranean context, "Atlantic" gardens based on turf grass species, are growing in popularity, even though these gardens are not adapted culturally or agronomically to Mediterranean areas. "Atlantic" gardens in the MRB require almost twice the amount of water per surface unit than the more "Mediterranean" adapted gardens based on local, less consuming plants. A detailed analysis to 120 households with gardens of six different municipalities of the MRB showed that, in summer, the water needs in the "Atlantic" gardens were around $30.1 \pm 8.31$ liters $/ \mathrm{m}^{2} \times$ week contrasting with the $18.5 \pm 9.4$ liters $/ \mathrm{m}^{2} \times$ week of Mediterranean gardens (Domene and Saurí, 2003). These differences on garden design as well as water demand are not independent of income. High income level owners are keener to create more water-consuming "Atlantic" gardens than the low or middles classes, which usually choose less demanding species. Moreover, households in the low income group show larger irrigation deficits than households in the high income group, especially during summer. In sum, high income households of the municipalities of the second periphery capture and use more water in their everyday life due to outdoor amenities than the low and middles income classes also living in low density housing. At the same time, low density housing belonging to low income groups may observe higher domestic water consumption than high density housing belonging to low income groups.

We argue that despite the economic (and also environmental) cost of maintaining gardens and swimming pools, the increase of these elements in the current geography of the second periphery of the Barcelona metropolitan region, especially in high income suburbs, can be explained partly by the symbolic representations of these specific landscapes. As already mentioned, private gardens and swimming pools have been related with a higher quality of life, contact with nature, quietness and privacy. Moreover, swimming pools and especially "Atlantic" gardens can be considered as positional goods, and therefore, confer prestige and social status to their owners. For those who choose the green lavish "Atlantic" gardens, water cost does not seem a limiting factor, as they assume the charge of maintaining the garden in their great aesthetic conditions. One of the most illustrative cases is the municipality of Sant Andreu de Llavaneres, one of the richest of the region and also one with the highest domestic water consumption. Here the suburban area is characterized by large, perfectly green gardens and enormous swimming pools. The owners of some of these gardens have brought water in trucks to irrigate their gardens in periods of water restrictions due to episodes of extreme drought.

\section{CREATING A PARTICULAR IDEAL HOME: MARKET AND ADVERTISING}

The globalization of consumption practices and the study of residential development patterns and housing preferences have received ample attention in the Anglo Saxon literature but less so in other contexts. As Leichenko and William (2005) point out, cultural, economic and political aspects of globalization interact with processes of urbanization to create a new landscape of housing consumption. These authors argue that globalization processes influence the housing preferences and the housing consumption decisions of the middle-income segment of the less developed urban residents. The exploration of the spaces of consumption includes a consideration not only of the places where consumption is highly evident (commercial areas, shopping malls, tourist spaces) but also the less visible spaces such as for example the internet, workplaces and homes.

The rise of suburbia and the rise of sub-urbanization is a clear testimony to the role of citizens as consumers (Robbins, 2007). However, owners are not alone in creating a particular ideal home. According to Robbins, their expansion is also the result of global economic processes that influenced consumer choices. Somehow, contextual pressures of the real estate, community, and municipality, act together to enforce a particular idea of dwelling. In the MRB new suburban lifestyles based on singlefamily housing types tend to become standardized among some middle and high -income segments of the Catalan population in a way similar to the suburban North-American landscapes. Marketing is progressively becoming more intrusive towards the population targeted. Automobile brands, bank brands, and of course the publicity of the property market incorporate in their advertisements elements related to suburban lifestyles: single-family housing, turf grass gardens, swimming pools, large autos.

In our context, suburban settings are sold as places where citizens can realise their housing preferences: a single family housing unit with a garden, with sufficient room nearby for the growing children to play 
but also a central location with respect to work. They are sold as places that combine features from both the city centre and rural areas, that are close to the city centre and rural environs that provide a spacious and green residential environment, stillness and quality of life (Figure 6).

Figure 6. Real state advertisements representing the suburban lifestyle as clean environment, quietness, nature, but near the advantages of the central city

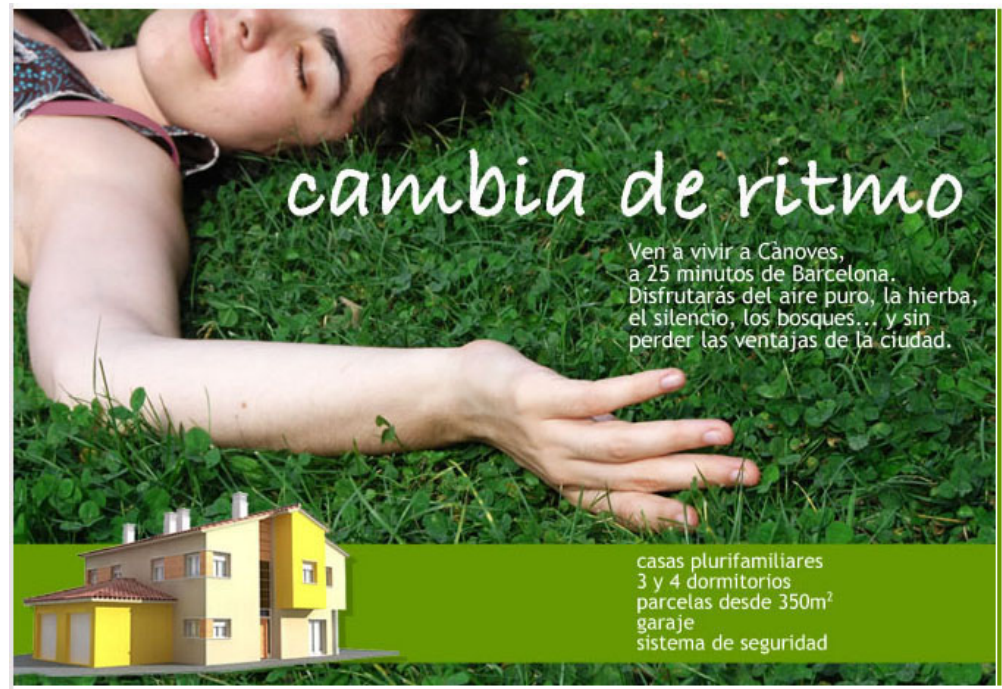

The advertisement of swimming pools have also occupied a great number of pages in real estate magazines in the period of the construction "boom". "Do you have a dream?. We do it real" [iTienes un sueño? Nosotros lo hacemos realidad; "Your own swimming pool. And why not?" [Su propia piscina. ¿Y por qué no? ], or "This summer they will have lots of happiness" [Este verano tendrán mucha felicidad] are some of the more recurrent slogans. They associate suburban lifestyles, together with a perfect green garden, with such transcendent aspects as better quality of life, happiness and family (Figure 7).

Figure 7. Swimming pool advertisement representing the swimming pool with quality of life, happiness and family.
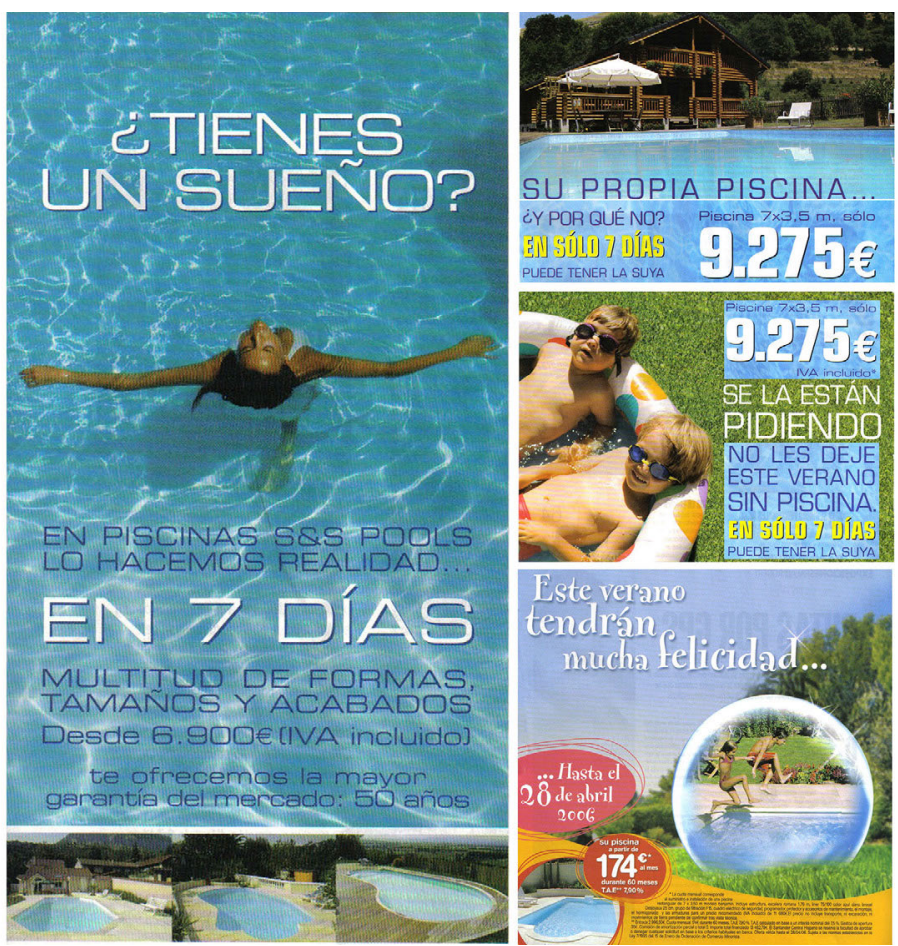
Moreover, and beyond these messages, during the economic boom associations between suburban lifestyles and values such as social status and prestige were also reinforced (See Figure 8). These images motivate certain consumers to accomplish their desire of acquire products that are related with patterns of consumption of the upper- classes. Thus, advertisement campaigns promote the illusion of goodness related to welfare. Although it is not clearly identified whether these campaigns are stirring this change of lifestyles or it is rather this new taste for "Atlantic" lifestyle which is provoking such advertisements, it can be argued that these synergies are slowly modifying the traditional sense of welfare in the Mediterranean urban landscapes towards a more "American" lifestyle.

Figure 8. Real state advertisement representing the single-family housing as a symbol of social success and family recognition.

\section{Comparte tu éxito}
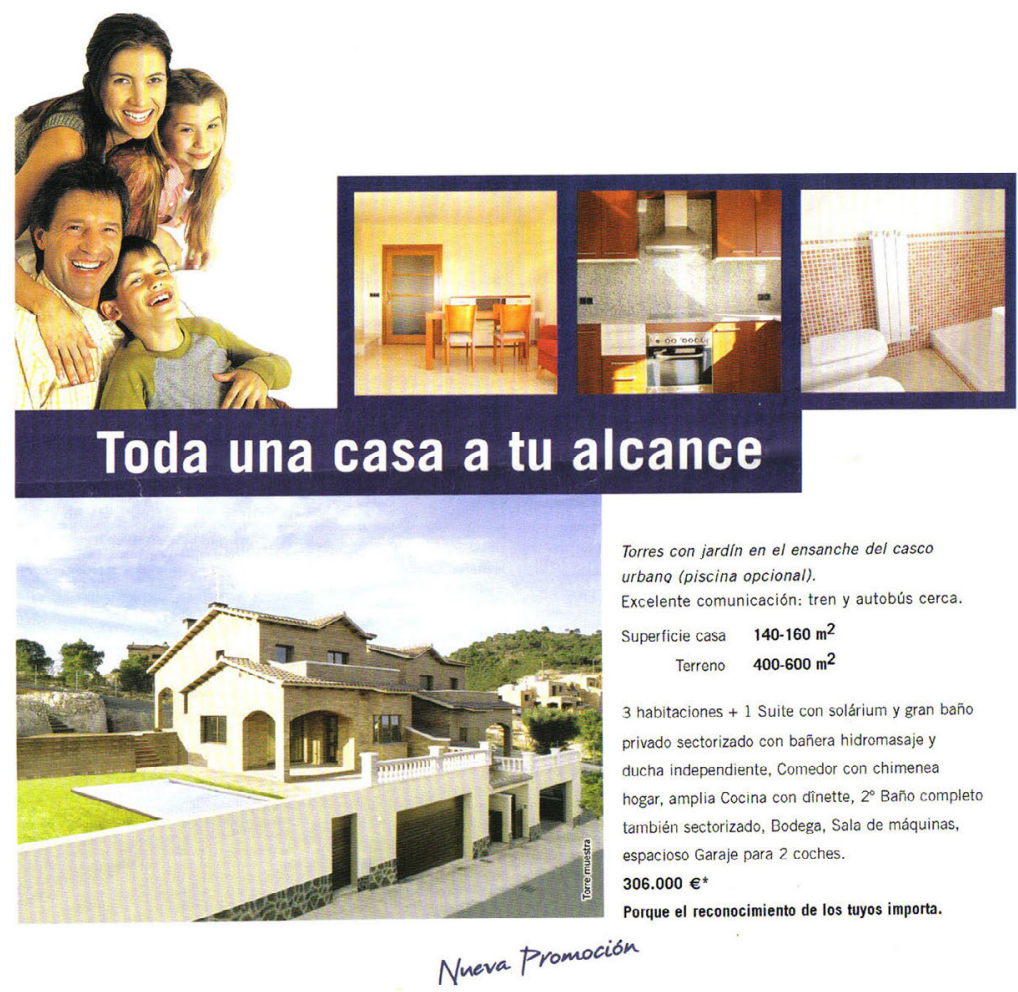

\section{CONCLUSIONS}

Single or detached family housing with gardens and swimming pools are fashionable products that have reached a wide range of the population in the MRB. Consumers are not alone in the decision of purchasing a certain way of life. Apart from the direct and real benefits of having a garden or a swimming pool and the different individual and deliberate options of consumption, their choices are influenced by structural factors in society such as urban structures and everyday life patterns.

Gardens and swimming pools are positional goods endowed with symbolic representations with important components of social expression. Their association with a better quality of life, quietness, happiness is other of the cultural components of these water uses within the household. Hence, domestic consumption as part of the patterns and styles of life plays a significant role in defining people's identities, experience and consciousness.

Although low density residential patterns have been claimed as less sustainable in social, economic and in environmental terms, they are more socially preferred by most groups of the population. At the 
same time, the general social perception that associates having a single-family housing with garden and swimming pool with a better quality of life, is also fostered by market and advertisement, especially during the economic boom of the first decade of the XXI century. During this period many times this suburban lifestyle was linked with fundamental values such as success, recognition, and membership of a certain social group, usually considered as better situated in the social hierarchy.

The proliferation of new geographies of water consumption based on new commodities such as swimming pools and green gardens becomes a very relevant question for water policy, since it exerts pressure on existing supplies and forces public authorities to either search for new supplies or to rely on economic, technological and/or behavioural instruments to curb consumption. Moreover, the new demand for water in the household sector responds to an unequal distribution, with high income social groups capturing a higher proportion of these consumption (along with energy consumption and waste generation), while water restriction policies (i.e. public pools) and increased water rates to cover the costs of the water cycle tends to affect mostly population already spending relatively little.

Finally, it is worth mentioning how these trends may be currently changing due to recurrent drought in the first decade of the century but, especially, to the high increase in water prices and taxes and the impact of the Spanish economic crisis beginning in 2008. These factors have contribute to a reduction of the domestic water consumption also in the low density households of the peripheral areas, where the Atlantic gardens with swimming pool may be no longer as widespread as before due to sharp increases in economic costs. In this sense, Atlantic gardens are clearly positional goods that concentrate in smaller groups of population that can still afford them despite the increase in water costs. In this situation, the argument of inequity gains strength because there is a wide sector of the population that are forced to change their water consumption habits, while there is another, much smaller, that maintains high consumptions and that is probably consuming other products also associated with social status and prestige less and less accessible to the population in general.

\section{REFERENCES:}

AGTHE, D., and R. B. BILLINGS. (1997): "Equity and conservation pricing policy for a government-run water utility". Journal of Water Supply Research and Technology AQUA, n. 46(5), pp. 253-60.

ARBUES, F, GARCIA-VALIÑAS, M.,A., AND MARTINEZ-ESPIÑEIRA, R. (2003): "Estimation of residencial water demand: a state-of-the-art review". The Journal of Socio-Economics, n. 32, pp. 81-102.

BAUMANN, D. D., J. BOLAND, and W. M. HANEMANN. (1998): Urban water demand management and planning. New York:McGraw-Hill.

BORMANN, F, et al. (1993): Redesigning the American Lawn: A Search for Environmental Harmony. New Haven and London: Yale University Press.

BREHENY, M. (1992): Sustainable development and urban form. European Research in Regional Science, Pion Limited, London.

CAMAGNI , R. and GIBELLI, M.C. (2002): I costi collettivi della città dispersa. Alinea Editrice s.r.l. Firenze.

CARNEY, E. (2007): "Suburbanizing Nature and Naturalizing Suburbanites: Outdoor-Living Culture and Landscapes of Growth", Western Historical Quarterly, n.38, pp. 477-500.

CATALAN, B., D. SAURÍ and P. SERRA (2008): "URBAN SPRAWL IN THE MEDITERRANEAN? PATTERNS OF GROWTH AND CHANGE IN THE BARCELONA METROPOLITAN REGION 1993-2000", Landscape and Urban Planning, n. 85.3/4, pp. 174-184.

COOLEN, H., and MEESTERS, J. (2012): "Private and public green spaces: meaningful but different settings", Journal of Housing and the Built Environment, n.27, pp. 49-67

CROSS, G. (2000): An All-Consuming Century: Why Commercialism Won in Modern America. NY, Columbia University Press. In: In SANNE, C. (2002): "Willing consumers-or locked -in? Policies for sustainable consumption”, Ecological Economics, n.42, pp. 273-287. 
DOMENE, E. and SAURI, D. (2003): "Modelos urbanos y consumo de agua. El riego de los jardines privados en la Región Metropolitana de Barcelona”, Investigaciones Geográficas, n. 32, pp. 5-17.

DOMENE, E. and SAURÍ, D. (2006): "Urbanization and water consumption: Influencing factors in the Metropolitan Region of Barcelona", Urban Studies, n. 43(9), pp. 1605-1623.

DOMENE, E., SAURÍ, D. and PARÉS, M. (2005): "Urbanization and Sustainable Resource Use: The Case of Garden Watering in the Metropolitan Region of Barcelona", Urban Geography, n. 26 (6), pp. 520-535.

DOUGLAS, S.J. (2000): "Narcisme as liberation", in Scanlom, J. (ed.), The gender and the Consumer Culture Reader. New York: New York University Press, pp. 267-282.

DOWLING, R. (2008): "Accommodating open plan: children clutter, and containment in suburban houses in Sydney, Australia", Environment and Planning A, n.40, pp. 536-549.

DUKE, J.M., EHEMANN R.W., and MACKENZIE J. (2002): "The distributional effects of water quantity management strategies: A spatial analysis", The Review of Regional Studies, n. 32(1), pp. 19-35.

DURÀ-GUIMERÀ, A. (2003): "Population, deconcentration and social restructuring in Barcelona, a European Mediterranean city", Cities, n. 20(6), pp. 387-394.

DZIEGIELEWSKI, B. (1999): "Management of water demand: Unresolved issues", Journal of Contemporary Water Research and Education, n.114, pp. 1-7.

EUROPEAN ENVIRONMENT AGENCY (2006): Urban sprawl in Europe. The ignored challenge, EEA Report $\mathrm{N}^{\circ} 10 / 2006$.

EUROPEAN ENVIRONMENTAL AGENCY ( 2007): Use of freshwater resources-outlook from EEA.

FONT, A., LLOP, C. and VILANOVA, J.M. (1999): La construcció del territori metropolità, morfogènesi de la regió urbana de Barcelona. Barcelona: MMAMB.

FOSTER, H. S. J., and BEATTIE B. R. (1981): "Urban residential demand for water in the United States: Reply". Land Economics, n.57(2), pp. 257-265.

FRIEDMAN, J. (1994): Cultural Identities and Global Process. London, UK, Sage.

HANKE, S.H. and MARÉ L. DE (1982): "Residential water demand: A pooled time-series cross-section study of Malmö, Sweden”, Water Resources Bulletin, n. 18(4), pp. 621-646.

HIRSCH, F. (1976): Social Limits to growth. London, Routeledge. Ed. 1995.

HOBSON, K. (2003): "Consumption, environmental sustainability and human geography in Australia: a missing research agenda?", Australian Geographical Studies, 41(2), pp. 148-155.

HOFFMANN, M., WORTHINGTON A. and HIGGS H. (2006): "Urban water demand with fixed volumetric charging in a large municipality: The case of Brisbane, Australia", The Australian Journal of Agricultural and Resource Economics, n. 50(3), pp. 347-359.

IERMB (2006): Enquesta de condicions de vida i hàbits de la población de Catalunya. Institut d'Estudis Regional i Metropolitans de Barcelona, Barcelona.

INDOVINA, F. (1990): Città difussa. Venecia, DAEST-IUAV.

JENKINS, V.S. (1994). "The Lawn: A history of an American obsession. Washington and London: Smithsonian Institute Press.

LEGALES, P., 2002, European Cities. Oxford, United Kingdom: Oxford University Press.

LEICHENKO, R.M. and WILLIAM, D.S. (2005): "Exporting the American Dream. The Globalization of Suburban Consumption Landscapes”. Regional Studies, n. 39 (2), pp. 241-253.

LLEONART, P. and GAROLA, À. (1998): "Les ciutats intermèdies i la conurbació metropolitana: a la recerca d'un model territorial pel segle XXI", Revista Econòmica de Catalunya, n. 33, pp. 117-141.

LOH, M. y COGHLAN, P. (2003): Domestic water use study: Perth, Western Australia 1998-2021. Water Corporations, Perth, Western Australia. 
LUPI, T. and MUSTERD, S. (2006): “The suburban 'community question'”, Urban Studies, n. 43(4), pp. 801-818.

MANSVELT, J. (2005): Geographies of Consumption. London, UK, Sage.

MARTÍNEZ-ESPIÑEIRA, R. (2002): "Residential water demand in the north west of Spain", Environmental and Resource Economics, n. 21(2), pp. 161-187.

MARTÍNEZ-ESPIÑEIRA, R. (2003): "Price specification issues under block tariffs: a Spanish case-study", Water Policy, n. 5 (3), pp. 237-256.

MARTÍNEZ-ESPIÑEIRA, R. and NAUGES, C. (2004): "Is domestic water consumption sensitive to price control?", Applied Economics, n. 36, pp. 1697-1703.

MAZZANTI, M. and MONTINI A. (2006): "The determinants of residential water demand: Empirical evidence for a panel of Italian municipalities", Applied Economics Letters, n. 13(2), pp. 107-118.

MIAOU, S. (1990): "A class of time-series urban water demand models with nonlinear climatic effects", Water Resources Research, n. 26 (2), pp. 169-178.

MILES and PADDISON (1998): "Urban Consumption: A Historiographical Note", Urban Studies, n. 35 (5-6), pp. 815-838.

MUÑOZ, F. (2003): "Lock living: Urban sprawl in Mediterranean cities", Cities, n. 20(6), pp. 381-385.

MUÑOZ, F. (2001): "La ciudad multiplicada: la metrópolis de los territoriantes", Revista de Arquitectura y Urbanismo del Colegio Oficial de Arquitectos de Madrid, n. 322, pp. 153-160.

NAUGES,C. and THOMAS A. (2000): "Privately operated water utilities, municipal price negotiation, and estimation of residential water demand: The case of France", Land Economics, n. 76(1), pp. 68-85.

NEL.LO, O. (1995): "Dinàmiques territorials i mobilitat urbana a la Regió Metropolitana de Barcelona", Papers. Regió Metropolitana de Barcelona, n.24, pp. 9-37.

NEL.LO, O. (2001): Ciutat de ciutats. Barcelona: Editorial Empúries.

NEWMAN, P. (1992): "THE COMPACT CITY: AN AUSTRALIAN PERSPECTIVE", Built Environment, n. 18, pp. 285-300.

OPALUCH, J. (1982): "Urban residential demand for water in the United States: Further discussion", Land Economics, n. 58(2), pp. 225-242.

PACIONE, M. (2003): "Urban environmental quality and human wellbeing- a social geographical perspective", Landscape and Urban Planning, n. 65, pp. 19-30.

PISMAN, A., ALLAERT, G. and LOMBAERDE, P. (2011): "Urban and suburban lifestyles and residential preferences in a highly urbanized society. Experiences from a case study in Ghent (Flanders, Belgium)", Urban Studies in Belgium, n. 1-2, pp. 89-104.

ROBBINS, P. (2007): Lawn People. Temple University Press, Philadelphia.

ROBBINS, P. and SHARP. J. (2003): "Producing and Consuming Chemicals: The Moral Economy of the American Lawn”, Economic Geography, n. 79(4), pp. 425-451

RUEDA, S. (2002): Barcelona, ciutat compacta i complexa, una visió de futur més sostenible. Barcelona: Ajuntament de Barcelona.

RUEDA, S. (1995): Ecologia Urbana. Barcelona, Beta Editorial.

SIMMEL, G. (1903): The metropolis mortal life, reprint in D. Levine (1971) Georg Simmel: In Individual and Social Form. Chicago, IL, Chicago University Press. In: Miles and Paddison, (1998): "Urban Consumption: A Historiographical Note", Urban Studies, n. 35 (5-6), pp. 815-823.

STEINBERG, T. (2006): American green: The Obsessive quest for the perfect lawn. New York: W.W. Norton and Co.

STEPHENSON, D. (1999): "Demand management theory", Water S A, n. 25(2), pp. 115-135. 
SYME, G. J. et al. (2004): "Predicting and understanding home garden water use", Landscape and Urban Planning, n. 68, pp. 121-128.

TEYSSOT, G. Ed (1999): The American lawn. New York: Princeton Architectural Press.

TRNKA et al. (2011): "Agroclimatic Conditions in Europe Under Climate Change", Global Change Biology, n. 17 (7), pp. 2298-2318.

VEBLEN, THORSTEIN, 1899, (Ed. 1965). The theory of the leisure class: an economist study. [Reprints of economic classics. Facsímil, NY: Macmillan, 1899]. NY, Augustus M. Kelley.

VIDAL, M. and DOMENE, E. (2005): "Urbanización y nuevos usos del agua: el caso de las piscinas en la Región Metropolitana de Barcelona". Paper presented in: "Congreso de la Asociación de geógrafos Españoles". October 2005. Santander, Spain.

VIDAL, M., DOMENE, E. and SAURI, D. (2011): "Changing geographies of water-related consumption: residential swimming pools in suburban Barcelona", Area, n. 43(1), pp. 67-75.

ZUKIN, S. (1998): "Urban lifestyles: Diversity and Standardisation in Spaces of Consumption". Urban Studies, n. 35 (5-6), pp. 825-839. 